\title{
Öğretim Elemanlarının İhtiyaç Belirleme Eğilimleri ile Eğitim Felsefesi İnançları Arasındaki İlişkinin İncelenmesi
}

\author{
Enver YARGI \\ Millî Eğitim Bakanlığ1 \\ enver.yargi1@gmail.com \\ ORCID ID: 0000-0001-8987-1360 \\ Sadık Yüksel SIVACI \\ Burdur Mehmet Akif Ersoy Üniversitesi \\ sysivaci@mehmetakif.edu.tr \\ ORCID ID: 0000-0002-9002-3155
}

\begin{tabular}{lrr} 
Araştırma Makalesi & DOI: $10.31592 /$ aeusbed.693771 \\
\hline Geliş Tarihi: 14.05 .2020 & Revize Tarihi: 13.11 .2020 & Kabul Tarihi: 22.02.2021
\end{tabular}

\section{Atıf Bilgisi}

Yarg1, E. ve Sıvacı, S. Y. (2021). Öğretim elemanlarının ihtiyaç belirleme eğilimleri ile eğitim felsefesi inançları arasındaki ilişkinin incelenmesi. Ahi Evran Üniversitesi Sosyal Bilimler Enstitüsü Dergisi, 7(1), 65-84.

\section{öz}

$\mathrm{Bu}$ araştırmanın temel amacı, öğretim elemanlarının ihtiyaç belirleme eğilimleri ile eğitim felsefesi inançları arasındaki ilişkinin incelenmesidir. Araştırma korelatif araştırma modelinde oluşturulmuştur. Araştırmanın çalışma grubu, kadrosu Eğitim Programları ve Öğretim anabilim dalında olan 150 öğretim elemanından oluşmaktadır. Araştırmanın modeli ihtiyaç belirleme eğilimleri ile eğitim amaçları arasındaki ilişkinin incelenmesi nedeniyle korelatif araştırma modelidir. Araştırma verileri SPSS paket programına işlenerek analiz edilmiştir. Araştırma sonucunda, İhtiyaç Belirleme Eğilimi Envanteri puan ortalamaları incelendiğinde, en yüksek puan ortalamasının betimsel yaklaşım eğiliminde, en düşük puan ortalamasının ise demokratik yaklaşım eğiliminde olduğu görülmüştür. Eğitim İnançları Ölçeği puan ortalamaları incelendiğinde, en yüksek puan ortalamasının varoluşçu eğitim inançları boyutunda olduğu, en düșük puan ortalamasının ise ilerlemeci eğitim inançları boyutunda olduğu görülmüştür. İhtiyaç belirleme eğilimleri ile eğitim inançları arasındaki ilişki incelendiğinde, analitik yaklaşım ile daimici ve esasicilik arasında pozitif yönlü, düşük kuvvette bir ilişki olduğu; ilerlemeci, yeniden kurmacı ve varoluşçu eğitim arasında ise negatif yönlü düşük kuvvette bir ilişki olduğu; betimsel yaklaşım ile daimici ve esasici yaklaşım arasında pozitif yönlü, düşük kuvvette bir ilişki olduğu; ilerlemeci, yeniden kurmacı ve varoluşçu eğitim arasında ise negatif yönlü düşük kuvvette bir ilişki olduğu; farklar yaklaşımı ile varoluşçu yaklaşım arasında pozitif yönlü düşük kuvvette bir ilişki olduğu, esasicilik arasında negatif yönlü, düşük kuvvette bir ilişki olduğu: demokratik yaklaşım ile yeniden kurmacılık arasında pozitif yönlü, düşük kuvvette bir ilişki olduğu, daimici ve esasici eğitim arasında negatif yönlü, düşük kuvvette bir ilişki olduğu görülmüştür.

Anahtar Kelimeler: Eğitim felsefesi inançları, ihtiyaç belirleme eğilimleri, öğretim elemanları.

\section{Examination Of The Relationship Between Instructors' Need Assessment Tendencies And Philosophy Of Education Beliefs}

\begin{abstract}
The main purpose of this research is to examine the relationship between the towards needs determination of the teaching staff and their belief in the philosophy of education. The research was conducted in the correlative research model. The study group of the research group consists of 150 instructors from Curriculum and Instruction Department. As a result of the study, when the average of the Needs Assessment Tendencies Inventory is analyzed, it is observed that the highest means tend to descriptive approach and the lowest scores tend to be democratic. When the relationship between the tendencies of need determination and education beliefs is examined, it is seen that there is a positive and low strength relationship between analytical approach and permanence. It was observed that there was a negative negative power relationship between analytical approach and progressive, reconstructive and existential education. A positive, low-power relationship was found between descriptive and permanent approach. There was a negative relationship between the descriptive approach and progressive, reconstructive and existential education. There was a positive low-power relationship between the difference approach and the existential approach. It was observed that there was a negative and low-strength relationship between the difference approach and the principality. There was a positive, low-power relationship between democratic approach and reconstruction. There was a negative, low-power relationship between democratic approach and permanent and essential education.
\end{abstract}

Keywords: Instructor's, need assessment tendencies, philosophy of education beliefs. 


\section{Giriş}

Eğitim ihtiyacı, yaşanan durum ile arzu edilen durum arasındaki uygun eğitim etkinlikleriyle giderilebilecek eksiklikler ya da açıklardır (Demirel, 2015; Küçükahmet, 1992; Taymaz, 1981). Bu eksiklik ve açıklar işin gerektirdiği yeterlikleri diğer bir ifadeyle öğretim hedeflerinin kaynağını oluşturur. Eğitim etkinliğinin verimi eğitim ihtiyacının doğru saptanma derecesine bağlıdır. $\mathrm{Bu}$ anlamda eğitim alan birey mutlu olabilir ve yürütmesi gereken etkinlikleri başarıyla ve yeterli bir şekilde yapabilecek gücü gösterebileceğinden doyum sağlayabilir. Doyuma bağlı olarak motivasyonu ve bilişsel, duyuşsal, devinişsel açıdan etkinlik gösterme gücü artar (Brandt, 2000).

Türk Dil Kurumu (TDK, 2019) ihtiyaç kelimesini gereksinim, güçlü istek, yoksunluk olarak tanımlamaktadır. Bir durumun iyileştirilebilmesi için ihtiyaçların ortaya çıkması ve bu ihtiyaçlara çözüm bulunması gerekmektedir (Çalışkan ve Çangal, 2013). İhtiyaç analizi kavramı eğitim bilimleri alanında uzun yıllardır kullanılmakla birlikte 1970'li yıllardan itibaren daha bilimsel olarak işlenmeye başlamıştır (Lepointe, 1992; Akt. Adıgüzel, 2016). Eğitim ihtiyacını belirlemede ilk aşama olarak ihtiyaç belirleme yöntemlerinden hangisinin kullanılması gerektiği belirlenmelidir (Brown, 1995). İhtiyaç belirleme yöntemleri bilinirse bu süreç daha iyi şekilde kavranabilir (Karacaoğlu, 2009).

Demirel (2015) ihtiyaç belirleme yaklaşımlarını; Farklar Yaklaşımı, Demokratik Yaklaşım Analitik Yaklaşım ve Betimsel Yaklaşım olarak dörde ayırmıştır. Farklar Yaklaşımı; gözlenen başarıyla beklenen başarıyı ortaya çıkarır, demokratik yaklaşım toplumdaki baskın grupların istekleri doğrultusunda ortaya çıkar, analitik yaklaşım gelecekte ortaya çıkması olası durumlardan yola çıkarken betimsel yaklaşım ise belirli olgu veya eğitim yaşantılarından ortaya çıkan durumlarla ilgilenir. Araştırma bu ihtiyaç belirleme yaklaşımları çerçevesinde gerçekleştirilmiştir.

Felsefenin en önemli alt dallarından birisi de eğitim felsefesidir. Duman'a (2008) göre eğitim felsefesi eğitim üzerine düşünmektir. Literatürdeki bu tanımlamalar incelendiğinde eğitim felsefesi eğitimde istenen hedeflere ulaşılabilmesini sağlamak için sistemli bir şekilde düşünmektir şeklinde tanımlanabilir. Bu araştırmada eğitim felsefeleri olarak; Daimicilik, Esasicilik, İlerlemecilik, Yeniden Kurmacılık ve Varoluşçuluk ele alınmıştır.

Daimicilik; idealizm ve realizm felsefelerine dayanır. Bu anlayışta öğretmen tamamıyla öğrencilerden daha bilgili olduğu için sınıfta merkezde ve en üst düzeydedir (Moss ve Lee, 2010). Bireyler insan doğası ve ahlaki ilkeler gibi değişmez gerçekler doğrultusunda sağlam ve doğru karakterli olarak yetiştirilmelidir (Doğanay ve Sarı, 2003). Bunun yanı sira daimicilere göre insan doğasının en önemli yanı akıldır. Bu nedenle, eğitimde insan zihninin gelişmesine (entelektüel eğitime) önem verilmesi gerekir (Demirel, 2007).

Esasicilik; realizm ve idealizm akımından ortaya çıkan bir eğitim felsefesidir. Esasici eğitim felsefesi, eğitimin yaygınlaştıılmasını ve entellektüel ölçütlerin daha iyiye yol almasını benimser. Bu yaklaşımda öğretmenin entellektüel boyutlarının; genel kültür, alan bilgisi ve meslek bilgisinin çok güçlü olması öngörülür (Duman, 2008).

İlerlemecilik; pragmatizmin eğitime uyarlanmasıyla oluşmuştur. "Bu akıma göre eğitim, toplumda geleneksel olarak devam eden standartları ve değişmezlikleri değil, sürekli değişen hayatı öğretmelidir" (Ergün, 2009). Çağdaş eğitim felsefelerinden olan ilerlemecilik rekabeti ortadan kaldıran, bireyselliği ön planda tutan ve mutlak doğruları reddeden bir eğitim felsefesidir denilebilir.

Varoluş̧̧u eğitim; varoluşçu felsefenin eğitime yansımasıdır. Varoluş̧̧ulukta bilgi edinmenin yolu sezgidir. Kendi varoluşunu yaratan tek varlık insandır (Duman, 2008). Bu bağlamda araştırmanın amacı öğretim elemanlarının ihtiyaç belirleme eğilimleri ile eğitim felsefesi inançları arasındaki ilişkinin belirlenmesi ve çeşitli değişkenler açısından incelenmesidir. 


\section{Yöntem}

$\mathrm{Bu}$ çalışmada nicel araştırma yöntemi kullanılmış veri toplama araçları olarak, Sıvacı (2016) tarafından olușturulan "Program Geliștirmede İhtiyaç Belirleme Eğilimleri Envanteri", Yılmaz, Altınkurt ve Çokluk (2011) tarafından geliştirilen "Eğitim İnançları Ölçeği" ve araştırmacı tarafından geliştirilen "Kişisel Bilgi Formu” kullanılmıştır.

\section{Araştırmanın Modeli}

Araştırmanın modeli ihtiyaç belirleme eğilimleri ile eğitim amaçları arasındaki ilişkinin incelenmesi nedeniyle korelatif araştırma modelidir. Korelatif araştırma, araştırmacının iki değişkeni ölçtüğü ve diş değişkenleri kontrol etmek için çok az çaba göstererek ya da hiç çaba göstermeden aralarındaki istatistiksel ilişkiyi (yani korelasyonu) değerlendirdiği bir tür deneysel olmayan araştırmadır. Değişkenler arasında bir ilişki varsa, araştırmacılar diğer değişkenleri tahmin etmek için bir değişken üzerindeki skorları kullanabilir (Price, Jhangiani ve Chiang, 2015; Price, Jhangiani, Chiang, Leighton ve Cuttler, 2017).

\section{Çalışma Grubu}

Araştırmanın çalışma grubu uygun örnekleme yöntemi ile seçilmiş öğretim elemanlarından oluşmaktadır. Uygun örnekleme, tesadüfi veya firsat örneklemesi olarak da adlandırılır. Popülasyona yakın, halihazırda elverişli bir popülasyondan bir örnek alındığı bir tekniktir. Genellikle daha hızlı ve ekonomiktir (Bhattacherjee, 2012; Kılıç, 2013; Westfall, 2009). Araştırmanın çalışma grubunda bulunan öğretim elemanlarına iliş̧in bilgiler Tablo 1 ve Tablo 2' de verilmiştir.

Tablo 1

Çalışma Grubuna Ait Demografik Değişkenler (1)

\begin{tabular}{|c|c|c|c|c|}
\hline \multirow[b]{3}{*}{ Yaş Aralığ } & \multicolumn{4}{|c|}{ Cinsiyet } \\
\hline & \multicolumn{2}{|c|}{ Kadın } & \multicolumn{2}{|c|}{ Erkek } \\
\hline & $\mathrm{n}$ & $\%$ & $\mathrm{n}$ & $\%$ \\
\hline $20-29$ & 20 & 69.0 & 9 & 31.0 \\
\hline $30-39$ & 23 & 46.0 & 27 & 54.0 \\
\hline $40-49$ & 22 & 52.4 & 20 & 47.6 \\
\hline $50-59$ & 8 & 44.4 & 10 & 55.6 \\
\hline 60 Yaş Üzeri & 8 & 72.7 & 3 & 27.3 \\
\hline Toplam & 81 & 54.0 & 69 & 46.0 \\
\hline
\end{tabular}

Tablo 1'e göre öğretim elemanlarının cinsiyete göre dağılımları incelendiğinde, 81'i (\%54) kadın, 69’u (\%46) erkek olmak üzere 150 öğretim elemanından oluşmaktadır.

Tablo 2

Çalışma Grubuna Ait Demografik Değiş̧enler (2)

\begin{tabular}{lcc}
\hline Akademik Unvan & n & \% \\
\hline Profesör Doktor & 16 & 10.7 \\
Doçent Doktor & 32 & 21.3 \\
Doktor Öğretim Üyesi & 47 & 31.3 \\
Araştırma Görevlisi & 50 & 33.3 \\
Öğretim Görevlisi & 5 & 3.4 \\
\hline Yürütülen Araştırma Projesi Sayısı & & \\
\hline 0 & 52 & 34.7 \\
$1-5$ & 56 & 37.3 \\
$6-10$ & 19 & 12.7 \\
$11-15$ & 13 & 8.7 \\
16 ve üzeri & 10 & 6.7 \\
\hline Yürütülen Tez Sayısı & & 44.0
\end{tabular}


$1-5$

$6-10$

$11-15$

16 ve üzeri

$\begin{array}{cc}36 & 24.0 \\ 22 & 14.7 \\ 17 & 11.3 \\ 9 & 6.0\end{array}$

Tablo 2 incelendiğinde çalışma grubunda bulunan öğretim elemanlarının, 16's1 (\%10.7) profesör doktor, 32'si (\%21.3) doçent doktor, 47'si (\%31.3) doktor öğretim üyesi, 50'si (\%33.3) araştırma görevlisi ve 5’i (\%3.4) öğretim görevlisi kadrosunda bulunmaktadır. Araştırmanın çalışma grubunda bulunan öğretim elemanlarından 52'si (\%34.7) sifir, 56's1 (\%37.3) 1-5 arasında, 19'u (\%12.7) 6-10 arasında, 13’ü (\%8.7) 11-15 arasında, 10’u (\%6.7) 16 ve üzeri araştırma projesi yürütmüştür. Yürütülen tez sayıları incelendiğinde, çalışma grubunda bulunan öğretim elemanlarının 66's1 (\%44) sifir, 36's1 (\%24) 1-5 arasında, 22'si (\%14.7) 6-10 arasında, 17'si (\%11.3) 11-15 arasinda ve 9'u (\%6) 16 ve üzeri tez yürüttüğü görülmektedir.

\section{Veri Toplama Araçları}

Araştırmada veri toplama araçları olarak, Sıvacı (2016) tarafından oluşturulan "Program Geliştirmede İhtiyaç Belirleme Eğilimleri Envanteri”, Yılmaz, Altınkurt ve Çokluk (2011) tarafından geliştirilen "Eğitim İnançları Ölçeği" ve araştırmacı tarafından geliştirilen "Kişisel Bilgi Formu" kullanılmıştır.

Program Geliştirmede İhtiyaç Belirleme Eğilimleri Envanteri, Sıvacı (2016) tarafından geliştirilmiştir. Envanter, Analitik Yaklaşım, Betimsel Yaklaşım, Demokratik Yaklaşım ve Farklar Yaklaşımı alt boyutlarından oluşmaktadır. Envanterde toplamda 12 madde bulunmaktadır. Sıralamaya dayalı bir yapıdadır. Artan puanlar eğilimdeki artışı göstermektedir. Her bölümden alınabilecek en yüksek puan 4, en düşük puan ise 1'dir. Her bölümün birinci maddesi Analitik Yaklaşım, ikinci maddesi Betimsel Yaklaşım, üçüncü maddesi Farklar Yaklaşımı, dördüncü maddesi ise Demokratik Yaklaşıma yönelik maddeleri içermektedir. Her bir bölümde sıralama yapıldığında 1 . Tercihler 4 puan, 2. Tercihler 3 puan, 3. Tercihler 2 puan, 4. Tercihler ise 1 puan üzerinden hesaplanmıştır. Analitik Yaklaşım alt boyutu .54; Betimsel Yaklaşım alt boyutu .51; Farklar Yaklaşımı alt boyutu .44 ve Demokratik Yaklaşım alt boyutu .49 güvenirlik katsayısına sahiptir. Ölçek, öğretim üyelerinin program geliştirmede ihtiyaç belirleme eğilimlerini saptamayı amaçlamaktadır (Sıvacı, 2017). Bu araştırmada da analitik yaklaşım alt boyutu .85 , betimsel yaklaşım alt boyutu , .83 , farklar yaklaşımı alt boyutu .73 ve demokratik yaklaşımı alt boyutu .77 güvenirlik katsayısına sahip olduğu görülmüştür.

Eğitim İnançları Ölçeği, Yılmaz, Altınkurt ve Çokluk (2011) tarafından geliştirilmiştir. Ölçek 154 öğretmen ve 305 öğretmen adayı olmak üzere toplam 459 kişiden oluşan bir örneklem üzerinde uygulanmıştır. Açımlayıcı faktör analizi sonucunda ölçeğin; Daimici, Esasici, İlerlemeci, Yeniden Kurmac1 ve Varoluşçu Eğitim felsefelerini içeren beş alt boyuttan ve beşli likert tipi 40 maddeden oluştuğu belirlenmiştir. Söz konusu ölçekte yer alan maddelerin faktör yük değerleri .42 ile .74; madde toplam korelasyonları .22 ile .90; güvenirlik katsayıları ise .70 ile .91 arasında değişmektedir. Ayrıca ölçeğin beș faktörlü yapısı, doğrulayıcı faktör analizi ile de doğrulanmıștır. Bu araştırmada da daimici eğitim boyutunda .83 , esasici eğitim boyutunda .87 , ilerlemeci eğitim boyutunda .92 , yeniden kurmac1 eğitim boyutunda .82 ve varoluş̧̧u eğitim boyutunda .90 güvenirlik katsayılarına sahip olduğu görülmektedir.

\section{Verilerin Toplanması ve Analizi}

Araştırmada, kullanılan ölçeklerin izinleri email yoluyla veri toplama araçlarını geliştiren araştırmacılardan alınmıştır. İnternet üzerinden çevrimiçi olarak uygulanmıştır. Anket linki mail ile çalışma grubunda bulunan tüm öğretim elemanlarına ulaştırılmıştır. Veri toplama süreci; 6 ay sürmüştür. Veri toplama süreci sonunda elde edilen datalar, SPSS paket programına aktarılmıştır. Veriler SPSS paket programına işlenmiş ve verilerin analizinde parametrik testler kullanılmış; iki kategorili değişkenler için t testi, üç ve daha fazla kategorileri bulunan değişkenlerin analizinde One- 
way ANOVA ve değişkenlerin birbirlerine etkisinin analizinde Pearson Korelasyon analizi kullanılmıştır.

\section{Bulgular}

$\mathrm{Bu}$ bölümde öğretim elemanlarının ihtiyaç belirleme eğilimleri ile eğitim inançlarına dair bulgulara yer verilmişstir.

Tablo 3

Puan Ortalamalarına Göre İhtiyaç Belirleme Eğilimleri

\begin{tabular}{lc}
\hline İhtiyaç Belirleme Yaklaşımları & $\overline{\mathbf{x}}$ \\
\hline Betimsel & 7.8667 \\
Analitik & 7.6733 \\
Farklar & 7.5667 \\
Demokratik & 6.8067 \\
\hline
\end{tabular}

Tablo 3 incelendiğinde ihtiyaç belirleme eğilimi envanteri puan ortalamalarında. en yüksek puan ortalamasının betimsel yaklaşım eğiliminde $(\bar{x}=7.8667)$, en düşük puan ortalamasının ise demokratik yaklaşım eğiliminde ( $\bar{x}=6.8067)$ olduğu görülmüştür. Diğer bir ifade ile çalışma grubunda bulunan öğretim elemanlarının, görece ihtiyaç belirleme yaklaşımlarından betimsel yaklaşımı tercih ettiği ifade edilebilir.

Tablo 4

Cinsiyet Değişkenine Göre İhtiyaç Belirleme Eğilimleri

\begin{tabular}{lcccccc}
\hline $\begin{array}{l}\text { İhtiyaç Belirleme } \\
\text { Yaklaşımları }\end{array}$ & Cinsiyet & $\mathbf{n}$ & $\overline{\mathbf{x}}$ & $\begin{array}{c}\text { Standart } \\
\text { Sapma }\end{array}$ & $\mathbf{t}$ & $\mathbf{p}$ \\
\hline \multirow{2}{*}{ Analitik } & Kadın & 81 & 7.6543 & 2.97977 & -.085 & .932 \\
& Erkek & 69 & 7.6957 & 2.93210 & & \\
Betimsel & Kadın & 81 & 7.7654 & 2.61855 & -.534 & .594 \\
\multirow{2}{*}{ Farklar } & Erkek & 69 & 7.9855 & 2.42228 & & \\
& Kadın & 81 & 7.8025 & 2.85228 & 1.068 & .287 \\
Demokratik & Erkek & 69 & 7.2899 & 2.99559 & & \\
& Kadın & 81 & 6.9012 & 3.20392 & .406 & .685 \\
\hline
\end{tabular}

Tablo 4 incelendiğinde, cinsiyet değişkenine göre ihtiyaç belirleme envanteri boyutlarında istatistiksel olarak anlamlı farklılık olmadığı görülmektedir ( $p>.05)$. Cinsiyet değişkenine göre ihtiyaç belirleme envanteri puan ortalamaları incelendiğinde, analitik yaklaşım toplam puanlarında kadınların puan ortalamasının $(\bar{x}=7.6543)$, erkeklerin puan ortalamasına $(\bar{x}=7.6957)$ göre düşük olduğu görülmektedir.

Betimsel yaklaşım eğilimi puan ortalamalarında, kadınların puan ortalamasının ( $\bar{x}=7.7654)$, erkeklerin puan ortalamasından $(\overline{\mathrm{x}}=7.9855)$ düşük olduğu görülmektedir. Farklar yaklaşımı eğilimi puan ortalamalarında, kadınların puan ortalamasının $(\overline{\mathrm{x}}=7.8025)$, erkeklerin puan ortalamasindan $(\bar{x}=7.2899)$ yüksek olduğu görülmektedir. Demokratik yaklaşım eğilimi puan ortalamalarında, kadınların puan ortalamasının $(\overline{\mathrm{x}}=6.9012)$, erkeklerin puan ortalamasından $(\overline{\mathrm{x}}=6.6957)$ yüksek olduğu görülmektedir.

Tablo 5

Yaş Değişkenine Göre İhtiyaç Belirleme Ĕgilimleri

\begin{tabular}{lccccc}
\hline $\begin{array}{l}\text { İhtiyaç } \\
\text { Belirleme } \\
\text { Yaklaşımları }\end{array}$ & Yaş Aralı̆̆ı & $\mathbf{n}$ & $\overline{\mathbf{x}}$ & $\mathbf{F}$ & $\mathbf{p}$ \\
\hline & & & & & \\
Analitik & $20-29$ & 29 & 8.3448 & & .291 \\
& $30-39$ & 50 & 7.9600 & 1.255 & \\
\hline
\end{tabular}




\begin{tabular}{lccccc}
\hline & 60 Yaş Üzeri & 11 & 6.4545 & & \\
Betimsel & $20-29$ & 29 & 8.3103 & & .381 \\
& $30-39$ & 50 & 8.2400 & & \\
& $40-49$ & 42 & 7.4048 & 1.055 & \\
Farklar & $50-59$ & 18 & 7.5000 & & .391 \\
& 60 Yaş Üzeri & 11 & 7.3636 & \\
& $20-29$ & 29 & 7.5862 & & \\
& $30-39$ & 50 & 7.9200 & & \\
& $40-49$ & 42 & 7.2619 & 1.035 & .082 \\
Demokratik & $50-59$ & 18 & 6.6667 & & \\
& 60 Yaş Üzeri & 11 & 8.5455 & & \\
& $20-29$ & 29 & 6.6207 & & \\
& $30-39$ & 50 & 5.9800 & & \\
& $40-49$ & 42 & 7.1429 & 2.111 & \\
\hline
\end{tabular}

Tablo 5 incelendiğinde, yaş değişkenine göre ihtiyaç belirleme envanteri boyutlarında istatistiksel olarak anlamlı farklılık olmadığı görülmektedir ( $>$ >.05). Yaş değişkenine göre ihtiyaç belirleme envanteri puan ortalamaları incelendiğinde, analitik yaklaşım toplam puanlarında 20-29 yaş aralığında olanların puan ortalamasının $(\overline{\mathrm{x}}=8.3448)$ en yüksek, 60 yaş ve üzeri yaş aralığında olanların puan ortalamasının $(\overline{\mathrm{x}}=6.4545)$ en düşük olduğu görülmektedir.

Betimsel yaklaşım eğilimi puan ortalamalarında, 20-29 yaş aralığında olanların puan ortalamasının ( $\overline{\mathrm{x}}=8.3103)$ en yüksek, 60 yaş ve üzeri yaş aralığında olanların puan ortalamasının $(\bar{x}=7.3636)$ en düşük olduğu görülmektedir. Farklar yaklaşımı eğilimi puan ortalamalarında, 60 yaş ve üzeri yaş aralığında bulunanların puan ortalamasının ( $\overline{\mathrm{x}}=8.5455)$ en yüksek, $50-59$ yaş aralığında bulunanların puan ortalamasının $(\overline{\mathrm{x}}=6.6667)$ en düşük olduğu görülmektedir. Demokratik yaklaşım eğilimi puan ortalamalarında, 60 yaş ve üzeri yaş aralığında bulunanların puan ortalamasının ( $\overline{\mathrm{x}}=8.2727)$ en yüksek, 30-39 yaş aralığında bulunanların puan ortalamasının $(\overline{\mathrm{x}}=5.9800)$ en düşük olduğu görülmektedir.

Tablo 6

Akademik Unvan Değişkenine İhtiyaç Belirleme Eğilimleri

\begin{tabular}{|c|c|c|c|c|c|}
\hline $\begin{array}{l}\text { İhtiyaç Belirleme } \\
\text { Yaklaşımları }\end{array}$ & Akademik Unvan & $\mathbf{n}$ & $\overline{\mathbf{x}}$ & $\mathbf{F}$ & $\mathbf{p}$ \\
\hline \multirow{5}{*}{ Analitik } & Profesör Doktor & 16 & 7.0625 & \multirow{5}{*}{2.852} & \multirow{5}{*}{.026} \\
\hline & Doçent Doktor & 32 & 7.0938 & & \\
\hline & Doktor Öğretim Üyesi & 47 & 7.9362 & & \\
\hline & Araştırma Görevlisi & 50 & 8.3200 & & \\
\hline & Öğretim Görevlisi & 5 & 4.4000 & & \\
\hline \multirow{5}{*}{ Betimsel } & Profesör Doktor & 16 & 7.8750 & \multirow{5}{*}{2.179} & \multirow{5}{*}{.074} \\
\hline & Doçent Doktor & 32 & 7.1875 & & \\
\hline & Doktor Öğretim Üyesi & 47 & 7.9149 & & \\
\hline & Araştırma Görevlisi & 50 & 8.4600 & & \\
\hline & Öğretim Görevlisi & 5 & 5.8000 & & \\
\hline \multirow{5}{*}{ Farklar } & Profesör Doktor & 16 & 8.3750 & \multirow{5}{*}{.506} & \multirow{5}{*}{.731} \\
\hline & Doçent Doktor & 32 & 7.4375 & & \\
\hline & Doktor Öğretim Üyesi & 47 & 7.5532 & & \\
\hline & Araştırma Görevlisi & 50 & 7.3200 & & \\
\hline & Öğretim Görevlisi & 5 & 8.4000 & & \\
\hline \multirow{5}{*}{ Demokratik } & Profesör Doktor & 16 & 8.1250 & \multirow{5}{*}{2.204} & \multirow{5}{*}{.071} \\
\hline & Doçent Doktor & 32 & 7.6875 & & \\
\hline & Doktor Öğretim Üyesi & 47 & 6.4043 & & \\
\hline & Araştırma Görevlisi & 50 & 6.1600 & & \\
\hline & Öğretim Görevlisi & 5 & 7.2000 & & \\
\hline
\end{tabular}


Tablo 6 incelendiğinde, akademik unvan değişkenine göre ihtiyaç belirleme envanteri boyutlarından sadece analitik yaklaşım eğilimi boyutunda istatistiksel olarak anlamlı farklılık olduğu görülmektedir $(\mathrm{p}<.05)$. Farklılığa ilişkin yapılan Scheffe posthoc analizi sonucunda anlamlı bir farklılığa ulaşılamamıştır ( $\mathrm{p}>.05)$. Akademik unvan değişkenine göre ihtiyaç belirleme envanteri puan ortalamaları incelendiğinde, analitik yaklaşım eğilimi puan ortalamalarında, en yüksek puan ortalamasının araştırma görevlisi öğretim elemanlarında $(\bar{x}=8.3200)$, en düşük puan ortalamasının ise öğretim görevlisi öğretim elemanlarında $(\overline{\mathrm{x}}=4.4000)$ olduğu görülmektedir.

Betimsel yaklaşım eğilimi puan ortalamalarında, en yüksek puan ortalamasının araştırma görevlisi öğretim elemanlarında $(\bar{x}=8.4600)$, en düşük puan ortalamasının ise öğretim görevlisi öğretim elemanlarında $(\overline{\mathrm{x}}=5.8000)$ olduğu görülmektedir. Farklar yaklaşımı eğilimi puan ortalamalarında, en yüksek puan ortalamasının öğretim görevlisi öğretim elemanlarında $(\bar{x}=8.4000)$, en düşük puan ortalamasının ise araştırma görevlisi öğretim elemanlarında ( $\overline{\mathrm{x}}=7.3200$ ) olduğu görülmektedir. Demokratik yaklaşım eğilimi puan ortalamalarında, en yüksek puan ortalamasının profesör doktor ögrretim elemanlarında $(\overline{\mathrm{x}}=8.1250)$, en düşük puan ortalamasının ise araştırma görevlisi öğretim elemanlarında $(\overline{\mathrm{x}}=6.1600)$ olduğu görülmektedir.

Tablo 7

Yürütülen Araştırma Projesi Sayısı Değişkenine Göre İhtiyaç Belirleme Eğilimleri

\begin{tabular}{|c|c|c|c|c|c|}
\hline $\begin{array}{l}\text { İhtiyaç Belirleme } \\
\text { Yaklaşımları }\end{array}$ & $\begin{array}{c}\text { Yürütülen Araştırma Projesi } \\
\text { Sayısı }\end{array}$ & $\mathbf{n}$ & $\overline{\mathbf{x}}$ & $\mathbf{F}$ & $\mathbf{p}$ \\
\hline \multirow{5}{*}{ Analitik } & Yok & 52 & 7.8654 & \multirow{5}{*}{2.152} & \multirow{5}{*}{.077} \\
\hline & $1-5$ & 56 & 8.1250 & & \\
\hline & $6-10$ & 19 & 6.3684 & & \\
\hline & $11-15$ & 13 & 8.0769 & & \\
\hline & 16 ve üzeri & 10 & 6.1000 & & \\
\hline \multirow{5}{*}{ Betimsel } & Yok & 52 & 8.0385 & \multirow{5}{*}{1.033} & \multirow{5}{*}{.392} \\
\hline & $1-5$ & 56 & 8.1429 & & \\
\hline & $6-10$ & 19 & 6.9474 & & \\
\hline & $11-15$ & 13 & 7.8462 & & \\
\hline & 16 ve üzeri & 10 & 7.2000 & & \\
\hline \multirow{5}{*}{ Farklar } & Yok & 52 & 7.4038 & \multirow{5}{*}{.201} & \multirow{5}{*}{.937} \\
\hline & $1-5$ & 56 & 7.5357 & & \\
\hline & $6-10$ & 19 & 8.1053 & & \\
\hline & $11-15$ & 13 & 7.6154 & & \\
\hline & 16 ve üzeri & 10 & 7.5000 & & \\
\hline \multirow{5}{*}{ Demokratik } & Yok & 52 & 6.4231 & \multirow{5}{*}{2.726} & \multirow{5}{*}{.032} \\
\hline & $1-5$ & 56 & 6.2143 & & \\
\hline & $6-10$ & 19 & 8.2632 & & \\
\hline & $11-15$ & 13 & 7.5385 & & \\
\hline & 16 ve üzeri & 10 & 8.4000 & & \\
\hline
\end{tabular}

Tablo 7 incelendiğinde, yürütülen araştırma sayısı değişkenine göre ihtiyaç belirleme envanteri boyutlarında istatistiksel olarak anlamlı farklılık olmadığı görülmektedir ( $p>05)$. Akademik unvan değişkenine göre ihtiyaç belirleme envanteri puan ortalamaları incelendiğinde. analitik yaklaşım eğilimi puan ortalamalarında, en yüksek puan ortalamasının 1-5 arasında proje yürüten öğretim elemanlarında $(\bar{x}=8.1250)$, en düşük puan ortalamasının ise 16 ve üzeri proje yürüten öğretim elemanlarında $(\overline{\mathrm{x}}=6.1000)$ olduğu görülmektedir.

Betimsel yaklaşım eğilimi puan ortalamalarında, en yüksek puan ortalamasının 1-5 arasında proje yürüten öğretim elemanlarında $(\overline{\mathrm{x}}=8.1429)$, en düşük puan ortalamasının ise 6-10 arasında proje yürüten öğretim elemanlarında $(\overline{\mathrm{x}}=6.9474)$ olduğu görülmektedir. Farklar yaklaşımı eğilimi puan ortalamalarında, en yüksek puan ortalamasının ise 6-10 arasında proje yürüten öğretim elemanlarında $(\overline{\mathrm{x}}=8.1053)$, en düşük puan ortalamasının ise hiç araştırma projesi yürütmemiş öğretim elemanlarında $(\overline{\mathrm{x}}=7.4038)$ olduğu görülmektedir. Demokratik yaklaşım eğilimi puan ortalamalarında, en yüksek puan ortalamasının ise 16 ve üzeri sayıda proje yürüten öğretim elemanlarında $(\overline{\mathrm{x}}=8.4000)$, en düşük 
puan ortalamasının ise 1-5 arasında proje yürüten öğretim elemanlarında ( $\bar{x}=6.2143$ ) olduğu görülmektedir.

Tablo 8

Yürütülen Tez Sayısı Değişkenine Göre İhtiyaç Belirleme Eğilimleri

\begin{tabular}{|c|c|c|c|c|c|}
\hline $\begin{array}{l}\text { İhtiyaç Belirleme } \\
\text { Yaklaşımları }\end{array}$ & $\begin{array}{l}\text { Yürüitülen } \\
\text { Tez Sayısı }\end{array}$ & $\mathbf{n}$ & $\overline{\mathbf{x}}$ & $\mathbf{F}$ & $\mathbf{p}$ \\
\hline \multirow{5}{*}{ Analitik } & Yok & 66 & 7.8182 & \multirow{5}{*}{2.698} & \multirow{5}{*}{.033} \\
\hline & $1-5$ & 36 & 8.5833 & & \\
\hline & $6-10$ & 22 & 6.9545 & & \\
\hline & $11-15$ & 17 & 7.2941 & & \\
\hline & 16 ve üzeri & 9 & 5.4444 & & \\
\hline \multirow{5}{*}{ Betimsel } & Yok & 66 & 8.0606 & \multirow{5}{*}{.976} & \multirow{5}{*}{.423} \\
\hline & $1-5$ & 36 & 8.2778 & & \\
\hline & $6-10$ & 22 & 7.3182 & & \\
\hline & $11-15$ & 17 & 7.1765 & & \\
\hline & 16 ve üzeri & 9 & 7.4444 & & \\
\hline \multirow{5}{*}{ Farklar } & Yok & 66 & 7.3636 & \multirow{5}{*}{.521} & \multirow{5}{*}{.720} \\
\hline & $1-5$ & 36 & 8.0556 & & \\
\hline & $6-10$ & 22 & 7.6818 & & \\
\hline & $11-15$ & 17 & 7.0000 & & \\
\hline & 16 ve üzeri & 9 & 7.8889 & & \\
\hline \multirow{5}{*}{ Demokratik } & Yok & 66 & 6.0152 & \multirow{5}{*}{3.443} & \multirow{5}{*}{.010} \\
\hline & $1-5$ & 36 & 6.6389 & & \\
\hline & $6-10$ & 22 & 7.7273 & & \\
\hline & $11-15$ & 17 & 7.8824 & & \\
\hline & 16 ve üzeri & 9 & 9.0000 & & \\
\hline
\end{tabular}

Tablo 8 incelendiğinde, yürütülen tez sayısı değişkenine göre ihtiyaç belirleme envanteri boyutlarından analitik ve demokratik yaklaşım değişkenlerinde istatistiksel olarak anlamlı farklılık olduğu görülmektedir $(\mathrm{p}<.05)$. Farklılıklara ilişkin yapılan Scheffe Posthoc analizi istatistiksel olarak anlamlı bir farlılık olmadığı görülmüştür ( $\mathrm{p}>.05)$. Yürütülen tez sayısı değişkenine göre ihtiyaç belirleme envanteri puan ortalamaları incelendiğinde, analitik yaklaşım eğilimi puan ortalamalarında, en yüksek puan ortalamasının 1-5 arasında tez yürüten öğretim elemanlarında $(\bar{x}=8.5833)$, en düşük puan ortalamasının ise 16 ve üzeri tez yürüten öğretim elemanlarında $(\bar{x}=5.4444)$ olduğu görülmektedir. Betimsel yaklaşım eğilimi puan ortalamalarında, en yüksek puan ortalamasının 1-5 arasında tez yürüten öğretim elemanlarında $(\bar{x}=8.2778)$, en düşük puan ortalamasının ise 11-15 arasında tez yürüten öğretim elemanlarında $(\bar{x}=7.1765)$ olduğu görülmektedir. Farklar yaklaşımı eğilimi puan ortalamalarında, en yüksek puan ortalamasının 1-5 arasında tez yürüten öğretim elemanlarında $(\overline{\mathrm{x}}=8.0556)$, en düşük puan ortalamasının ise $11-15$ arasında tez yürüten öğretim elemanlarında ( $\bar{x}=7.0000)$ olduğu görülmektedir. Demokratik yaklaşım eğilimi puan ortalamalarında, en yüksek puan ortalamasının ise 16 ve üzeri sayıda tez yürüten öğretim elemanlarında $(\bar{x}=9.000)$, en düşük puan ortalamasının ise hiç tez yürütmemiş öğretim elemanlarında ( $\bar{x}=6.0152)$ olduğu görülmektedir.

Tablo 9

Puan Ortalamalarına Göre Eğitim İnançları

\begin{tabular}{lcc}
\hline Ĕgitim İnançları Boyutları & $\overline{\mathbf{x}}$ & Boyuttan Alınabilecek En Yüksek Puan \\
\hline Daimici & 26.9533 & 40 \\
Esasici & 13.8933 & 25 \\
İlerlemeci & 47.4200 & 65 \\
Yeniden Kurmacı & 25.2133 & 35 \\
Varoluşçu & 26.2000 & 35 \\
\hline
\end{tabular}

Tablo 9 incelendiğinde, eğitim inançları ölçeği puan ortalamalarında, en yüksek puan ortalamasının varoluşçu eğitim inançları boyutunda $(\bar{x}=26.2000)$ olduğu, en düşük puan ortalamasının ise esasici eğitim inançları boyutunda ( $\bar{x}=13.8933)$ olduğu görülmüştür. Diğer bir ifade ile çalışma 
grubunda bulunan öğretim elemanlarının, görece varoluşçu eğitim inancını benimsedikleri ifade edilebilir.

Tablo 10

Cinsiyet Değişkenine Göre Ĕ̈itim İnançlart

\begin{tabular}{|c|c|c|c|c|c|c|}
\hline $\begin{array}{l}\text { Eğitim İnançları } \\
\text { Boyutları }\end{array}$ & Cinsiyet & $\mathbf{n}$ & $\overline{\mathbf{x}}$ & $\begin{array}{c}\text { Standart } \\
\text { Sapma }\end{array}$ & $\mathbf{t}$ & $\mathbf{p}$ \\
\hline \multirow{2}{*}{ Daimici } & Kadin & 81 & 26.8025 & 6.89097 & \multirow{2}{*}{-.307} & \multirow{2}{*}{.759} \\
\hline & Erkek & 69 & 27.1304 & 6.19277 & & \\
\hline \multirow{2}{*}{ Esasici } & Kadın & 81 & 14.4074 & 4.76911 & \multirow{2}{*}{1.319} & \multirow{2}{*}{.189} \\
\hline & Erkek & 69 & 13.2899 & 5.49358 & & \\
\hline \multirow{2}{*}{ İlerlemeci } & Kadın & 81 & 47.6543 & 10.70416 & \multirow{2}{*}{.292} & \multirow{2}{*}{.771} \\
\hline & Erkek & 69 & 47.1449 & 10.63191 & & \\
\hline \multirow{2}{*}{ Yeniden Kurmacı } & Kadın & 81 & 25.6420 & 5.20170 & \multirow{2}{*}{1.066} & \multirow{2}{*}{.288} \\
\hline & Erkek & 69 & 24.7101 & 5.44789 & & \\
\hline \multirow{2}{*}{ Varoluşçu } & Kadın & 81 & 26.3086 & 6.21016 & \multirow[t]{2}{*}{.218} & \multirow[t]{2}{*}{.828} \\
\hline & Erkek & 69 & 26.0725 & 6.94584 & & \\
\hline
\end{tabular}

Tablo 10 incelendiğinde, cinsiyet değişkenine göre eğitim inançları ölçeği puanlarında istatistiksel olarak anlamlı farklılık olmadığı görülmektedir $(\mathrm{p}>.05)$. Cinsiyet değişkenine göre eğitim inançları puan ortalamaları incelendiğinde daimici eğitim boyutunda, kadınların puan ortalamasının $(\overline{\mathrm{x}}=26.8025)$, erkeklerin puan ortalamasından ( $\overline{\mathrm{x}}=27.1304)$ düşük olduğu görülmektedir.

Esasici eğitim boyutunda, kadınların puan ortalamasının $(\overline{\mathrm{x}}=14.4074)$, erkeklerin puan ortalamasından ( $\overline{\mathrm{x}}=13.2899)$ daha yüksek olduğu görülmektedir. İlerlemeci eğitim boyutunda, kadınların puan ortalamasının ( $\overline{\mathrm{x}}=47.6543)$, erkeklerin puan ortalamasından $(\overline{\mathrm{x}}=47.1449)$ daha yüksek olduğu görülmektedir. Yeniden kurmacı eğitim boyutunda, kadınların puan ortalamasının $(\overline{\mathrm{x}}=25.6420)$, erkeklerin puan ortalamasından $(\overline{\mathrm{x}}=24.7101)$ daha yüksek olduğu görülmektedir. Varoluşçu eğitim boyutunda, kadınların puan ortalamasının $(\overline{\mathrm{x}}=26.3086)$, erkeklerin puan ortalamasından $(\bar{x}=26.0725)$ daha yüksek olduğu görülmektedir.

Tablo 11

Yaş Değişkenine Göre Ĕ̈itim Inançları

\begin{tabular}{|c|c|c|c|c|c|}
\hline Eğitim İnançları Boyutları & Yaş Aralığı & $\mathbf{n}$ & $\overline{\mathbf{x}}$ & $\mathbf{F}$ & $\mathbf{p}$ \\
\hline \multirow{5}{*}{ Daimici } & $20-29$ & 29 & 27.2414 & \multirow{5}{*}{2.122} & \multirow{5}{*}{.081} \\
\hline & $30-39$ & 50 & 26.7000 & & \\
\hline & $40-49$ & 42 & 27.6905 & & \\
\hline & $50-59$ & 18 & 28.5556 & & \\
\hline & 60 Yaş Üzeri & 11 & 21.9091 & & \\
\hline \multirow{5}{*}{ Esasici } & $20-29$ & 29 & 15.2759 & \multirow{5}{*}{.923} & \multirow{5}{*}{.45} \\
\hline & $30-39$ & 50 & 14.0000 & & \\
\hline & $40-49$ & 42 & 13.0000 & & \\
\hline & $50-59$ & 18 & 13.2778 & & \\
\hline & 60 Yaş Üzeri & 11 & 14.1818 & & \\
\hline \multirow{5}{*}{ İlerlemeci } & $20-29$ & 29 & 48.7931 & \multirow{5}{*}{.510} & \multirow{5}{*}{.728} \\
\hline & $30-39$ & 50 & 47.1600 & & \\
\hline & $40-49$ & 42 & 47.1667 & & \\
\hline & $50-59$ & 18 & 48.7222 & & \\
\hline & 60 Yaş Üzeri & 11 & 43.8182 & & \\
\hline \multirow{6}{*}{ Yeniden Kurmacı } & $20-29$ & 29 & 26.0690 & \multirow{5}{*}{1.029} & \multirow{5}{*}{.394} \\
\hline & $30-39$ & 50 & 24.6000 & & \\
\hline & $40-49$ & 42 & 25.0238 & & \\
\hline & $50-59$ & 18 & 26.8889 & & \\
\hline & 60 Yaş Üzeri & 11 & 23.7273 & & \\
\hline & $20-29$ & 29 & 26.8276 & \multirow{3}{*}{.509} & \\
\hline \multirow[t]{2}{*}{ Varoluşçu } & $30-39$ & 50 & 25.4400 & & \multirow[t]{2}{*}{.729} \\
\hline & $40-49$ & 42 & 26.2143 & & \\
\hline
\end{tabular}




\begin{tabular}{rrr}
\hline $50-59$ & 18 & 27.7222 \\
60 Yaş Üzeri & 11 & 25.4545 \\
\hline
\end{tabular}

Tablo 11 incelendiğinde, yaş değişkenine göre eğitim inançları ölçeği boyutlarında istatistiksel olarak anlamlı farklılık olmadığ 1 görülmektedir ( $p>.05)$. Yaş değişkenine göre eğitim inançları ölçeği puan ortalamaları incelendiğinde, daimici eğitim boyutu toplam puanlarında 50-59 yaş aralığında olanların puan ortalamasının ( $\overline{\mathrm{x}}=28.5556)$ en yüksek, 60 yaş ve üzeri yaş aralığında olanların puan ortalamasının ( $\overline{\mathrm{x}}=21.9091)$ en düşük olduğu görülmektedir.

Esasici eğitim boyutu puan ortalamalarında, 20-29 yaş aralığında olanların puan ortalamasının ( $\overline{\mathrm{x}}=15.2759)$ en yüksek, 40-49 yaş aralığında olanların puan ortalamasının $(\overline{\mathrm{x}}=13.0000)$ en düşük olduğu görülmektedir. İlerlemeci eğitim boyutu puan ortalamalarında 20-29 yaş aralığında olanların puan ortalamasının $(\bar{x}=48.7931)$ en yüksek, 60 yaş ve üzeri yaş aralığında bulunanların puan ortalamasının ( $\overline{\mathrm{x}}=43.8182)$ en düşük olduğu görülmektedir. Yeniden kurmac1 eğitim boyutu puan ortalamalarında, 50-59 yaş aralığında olanların puan ortalamasının ( $\overline{\mathrm{x}}=26.8889)$ en yüksek, 60 yaş ve üzeri yaş aralığında olanların puan ortalamasının ( $\overline{\mathrm{x}}=23.7273)$ en düşük olduğu görülmektedir. Varoluşçu eğitim boyutu puan ortalamalarında, 50-59 yaş aralığında olanların puan ortalamasının ( $\overline{\mathrm{x}}=27.7222)$ en yüksek, 30-39 yaş aralığında olanların puan ortalamasının $(\overline{\mathrm{x}}=25.4400)$ en düşük olduğu görülmektedir.

Tablo 12

Akademik Unvan Değişkenine Göre Ĕ̈itim İnançları

\begin{tabular}{|c|c|c|c|c|c|}
\hline $\begin{array}{l}\text { Eğitim İnançları } \\
\text { Boyutları }\end{array}$ & Akademik Unvan & $\mathbf{n}$ & $\overline{\mathbf{x}}$ & $\mathbf{F}$ & $\mathbf{p}$ \\
\hline \multirow{5}{*}{ Daimici } & Profesör Doktor & 16 & 23.5000 & \multirow{5}{*}{2.219} & \multirow{5}{*}{.070} \\
\hline & Doçent Doktor & 32 & 27.1875 & & \\
\hline & Doktor Öğretim Üyesi & 47 & 27.7660 & & \\
\hline & Araştırma Görevlisi & 50 & 27.6400 & & \\
\hline & Öğretim Görevlisi & 5 & 22.0000 & & \\
\hline \multirow{5}{*}{ Esasici } & Profesör Doktor & 16 & 13.5625 & \multirow{5}{*}{2.218} & \multirow{5}{*}{.070} \\
\hline & Doçent Doktor & 32 & 14.3438 & & \\
\hline & Doktor Öğretim Üyesi & 47 & 12.5957 & & \\
\hline & Araştırma Görevlisi & 50 & 15.2400 & & \\
\hline & Öğretim Görevlisi & 5 & 10.8000 & & \\
\hline \multirow{5}{*}{ İlerlemeci } & Profesör Doktor & 16 & 47.2500 & \multirow{5}{*}{1.536} & \multirow{5}{*}{.195} \\
\hline & Doçent Doktor & 32 & 44.2188 & & \\
\hline & Doktor Öğretim Üyesi & 47 & 48.6170 & & \\
\hline & Araştırma Görevlisi & 50 & 47.6400 & & \\
\hline & Öğretim Görevlisi & 5 & 55.0000 & & \\
\hline \multirow{5}{*}{ Yeniden Kurmacı } & Profesör Doktor & 16 & 25.5625 & \multirow{5}{*}{.823} & \multirow{5}{*}{.513} \\
\hline & Doçent Doktor & 32 & 24.5000 & & \\
\hline & Doktor Öğretim Üyesi & 47 & 25.5532 & & \\
\hline & Araştırma Görevlisi & 50 & 24.8800 & & \\
\hline & Öğretim Görevlisi & 5 & 28.8000 & & \\
\hline \multirow{5}{*}{ Varoluşçu } & Profesör Doktor & 16 & 26.9375 & \multirow{5}{*}{.985} & \multirow{5}{*}{.418} \\
\hline & Doçent Doktor & 32 & 24.5625 & & \\
\hline & Doktor Öğretim Üyesi & 47 & 26.9574 & & \\
\hline & Araştırma Görevlisi & 50 & 26.0000 & & \\
\hline & Öğretim Görevlisi & 5 & 29.2000 & & \\
\hline
\end{tabular}

Tablo 12 incelendiğinde, akademik unvan değişkenine göre eğitim inançları ölçeği boyutlarında istatistiksel olarak anlamlı farklılık olmadığ görülmektedir ( $p>.05)$. Akademik unvan değiş̧enine göre eğitim inançları boyutları puan ortalamaları incelendiğinde, daimici eğitim boyutu puan ortalamalarında, en yüksek puan ortalamasının doktor öğretim üyesi öğretim elemanlarında $(\overline{\mathrm{x}}=27.7660)$, en düşük puan ortalamalarının ise öğretim görevlisi öğretim elemanlarında $(\overline{\mathrm{x}}=22.0000)$ olduğu görülmektedir. 
Esasici eğitim boyutu puan ortalamalarında, en yüksek puan ortalamasının araştırma görevlisi öğretim elemanlarında $(\overline{\mathrm{x}}=15.2400)$, en düşük puan ortalamasının ise öğretim görevlisi öğretim elemanlarında ( $\overline{\mathrm{x}}=10.8000)$ olduğu görülmektedir. İlerlemeci eğitim boyutu puan ortalamalarında, en yüksek puan ortalamasının öğretim görevlisi öğretim elemanlarında $(\overline{\mathrm{x}}=55.0000)$, en düşük puan ortalamasının ise doçent doktor öğretim elemanlarında $(\overline{\mathrm{x}}=44.2188)$ olduğu görülmektedir. Yeniden kurmacı eğitim boyutu puan ortalamalarında, en yüksek puan ortalamasının öğretim görevlisi öğretim elemanlarında ( $\overline{\mathrm{x}}=28.8000)$, en düşük puan ortalamasının ise doçent doktor öğretim elemanlarında $(\overline{\mathrm{x}}=24.5000)$ olduğu görülmektedir. Varoluş̧̧u eğitim boyutu puan ortalamalarında, en yüksek puan ortalamasının öğretim görevlisi öğretim elemanlarında $(\bar{x}=29.2000)$, en düşük puan ortalamasının ise doçent doktor öğretim elemanlarında $(\bar{x}=24.5625)$ olduğu görülmektedir.

Tablo 13

Yürütülen Araştırma Sayısı Değişkenine Göre Eğitim İnançları

\begin{tabular}{|c|c|c|c|c|c|c|}
\hline $\begin{array}{l}\text { Eğitim İnançları } \\
\text { Boyutları }\end{array}$ & & $\mathbf{n}$ & $\overline{\mathbf{x}}$ & $\mathbf{F}$ & $\mathbf{p}$ & Fark \\
\hline \multirow{5}{*}{ Daimici } & Yok & 52 & 27.9231 & \multirow{5}{*}{1.155} & \multirow{5}{*}{.333} & \multirow{10}{*}{$1-5$ ve Yok } \\
\hline & $1-5$ & 56 & 27.0000 & & & \\
\hline & $6-10$ & 19 & 26.5789 & & & \\
\hline & $11-15$ & 13 & 26.3077 & & & \\
\hline & 16 ve üzeri & 10 & 23.2000 & & & \\
\hline \multirow{5}{*}{ Esasici } & Yok & 52 & 15.8269 & \multirow{5}{*}{5.232} & \multirow{5}{*}{.001} & \\
\hline & $1-5$ & 56 & 11.9107 & & & \\
\hline & $6-10$ & 19 & 12.8421 & & & \\
\hline & $11-15$ & 13 & 16.0000 & & & \\
\hline & 16 ve üzeri & 10 & 14.2000 & & & \\
\hline \multirow{5}{*}{ İlerlemeci } & Yok & 52 & 47.0577 & \multirow{5}{*}{2.945} & \multirow{5}{*}{.022} & \multirow{5}{*}{$1-5$ ile $11-15$} \\
\hline & $1-5$ & 56 & 50.4107 & & & \\
\hline & $6-10$ & 19 & 45.2105 & & & \\
\hline & $11-15$ & 13 & 40.3846 & & & \\
\hline & 16 ve üzeri & 10 & 45.9000 & & & \\
\hline \multirow{5}{*}{ Yeniden Kurmacı } & Yok & 52 & 25.3846 & \multirow{5}{*}{.409} & \multirow{5}{*}{.802} & \\
\hline & $1-5$ & 56 & 25.5714 & & & \\
\hline & $6-10$ & 19 & 25.0000 & & & \\
\hline & $11-15$ & 13 & 23.5385 & & & \\
\hline & 16 ve üzeri & 10 & 24.9000 & & & \\
\hline \multirow{5}{*}{ Varoluşçu } & Yok & 52 & 25.3269 & \multirow{5}{*}{1.410} & \multirow{5}{*}{.233} & \\
\hline & $1-5$ & 56 & 27.7500 & & & \\
\hline & $6-10$ & 19 & 25.8947 & & & \\
\hline & $11-15$ & 13 & 24.1538 & & & \\
\hline & 16 ve üzeri & 10 & 25.3000 & & & \\
\hline
\end{tabular}

Tablo 13 incelendiğinde, yürütülen araştırma sayısı değişkenine göre eğitim inançları ölçeğinde esasici ve ilerlemeci eğitim boyutlarında istatistiksel olarak anlamlı farklılık olduğu görülmektedir $(\mathrm{p}<.05)$. Esasici eğitim boyutundaki farklılığa ilişkin yapılan Scheffe post hoc analizi sonucunda, farklılığın kaynağının 1-5 arasında proje yürüten öğretim elemanlarının ortalamaları ile hiç proje yürütmeyen öğretim elemanları arasındaki farktan kaynaklandığı görülmektedir. İlerlemeci eğitim boyutundaki farklılığa ilișkin yapılan Scheffe post hoc analizi sonucunda, farklılığının kaynağının 1-5 arasında proje yürüten öğretim elemanlarının puan ortalamaları ile 11-15 arasında proje yürüten öğretim elemanları arasındaki farktan kaynaklandığı görülmektedir.

Yürütülen araştırma sayısı değişkenine göre eğitim inançları boyutları puan ortalamaları incelendiğinde, daimici eğitim boyutu puan ortalamalarında, en yüksek puan ortalamasının hiç proje yürütmeyen öğretim elemanlarında $(\overline{\mathrm{x}}=27.9231)$, en düşük puan ortalamasının ise 16 ve üzeri proje yürüten öğretim elemanlarında ( $\bar{x}=23.2000)$ olduğu görülmektedir. Esasici eğitim inancı boyutu puan ortalamalarında, en yüksek puan ortalamasının 11-15 arasında proje yürüten öğretim elemanlarında $(\overline{\mathrm{x}}=16.0000)$, en düşük puan ortalamasının ise 1-5 arasında proje yürüten öğretim elemanlarında ( $\overline{\mathrm{x}}=11.9170)$ olduğu görülmektedir. İlerlemeci eğitim inancı boyutu puan ortalamalarında, en yüksek 
puan ortalamasının 1-5 arasında proje yürüten öğretim elemanlarında $(\bar{x}=50.4107)$, en düşük puan ortalamasının ise 11-15 arasında proje yürüten öğretim elemanlarında $(\bar{x}=40.3846)$ olduğu görülmektedir. Yeniden kurmacı eğitim inancı boyutu puan ortalamalarında, en yüksek puan ortalamasının 1-5 arasında proje yürüten öğretim elemanlarında $(\overline{\mathrm{x}}=25.5714)$, en düşük puan ortalamasının ise 11-15 arasında proje yürüten öğretim elemanlarında $(\overline{\mathrm{x}}=23.5383)$ olduğu görülmektedir. Varoluşçu eğitim inancı boyutu puan ortalamalarında en yüksek puan ortalamasının 15 arasında proje yürüten öğretim elemanlarında $(\bar{x}=27.7500)$, en düşük puan ortalamasının ise 11-15 arasında proje yürüten öğretim elemanlarında $(\overline{\mathrm{x}}=24.1538)$ olduğu görülmektedir.

Tablo 14

Yürütülen Tez Sayısı Değişkenine Göre Eğitim İnançları

\begin{tabular}{|c|c|c|c|c|c|}
\hline $\begin{array}{l}\text { Eğitim İnançları } \\
\text { Boyutları }\end{array}$ & $\begin{array}{c}\text { Yürütülen Tez } \\
\text { Sayısı }\end{array}$ & $\mathbf{n}$ & $\overline{\mathbf{x}}$ & $\mathbf{F}$ & $\mathbf{p}$ \\
\hline \multirow{5}{*}{ Daimici } & Yok & 66 & 27.5455 & \multirow{5}{*}{.965} & \multirow{5}{*}{.429} \\
\hline & $1-5$ & 36 & 27.4167 & & \\
\hline & $6-10$ & 22 & 25.4545 & & \\
\hline & $11-15$ & 17 & 27.2353 & & \\
\hline & 16 ve üzeri & 9 & 23.8889 & & \\
\hline \multirow{5}{*}{ Esasici } & Yok & 66 & 14.2576 & \multirow{5}{*}{.345} & \multirow{5}{*}{.847} \\
\hline & $1-5$ & 36 & 13.5000 & & \\
\hline & $6-10$ & 22 & 13.5000 & & \\
\hline & $11-15$ & 17 & 14.4706 & & \\
\hline & 16 ve üzeri & 9 & 12.6667 & & \\
\hline \multirow{5}{*}{ İlerlemeci } & Yok & 66 & 49.2273 & \multirow{5}{*}{1.706} & \multirow{5}{*}{.152} \\
\hline & $1-5$ & 36 & 47.1111 & & \\
\hline & $6-10$ & 22 & 45.7273 & & \\
\hline & $11-15$ & 17 & 42.2941 & & \\
\hline & 16 ve üzeri & 9 & 49.2222 & & \\
\hline \multirow{5}{*}{ Yeniden Kurmac1 } & Yok & 66 & 25.4242 & \multirow{5}{*}{.365} & \multirow{5}{*}{.833} \\
\hline & $1-5$ & 36 & 24.7778 & & \\
\hline & $6-10$ & 22 & 25.0909 & & \\
\hline & $11-15$ & 17 & 24.5882 & & \\
\hline & 16 ve üzeri & 9 & 26.8889 & & \\
\hline \multirow{5}{*}{ Varoluşçu } & Yok & 66 & 26.8939 & \multirow{5}{*}{.622} & \multirow{5}{*}{.647} \\
\hline & $1-5$ & 36 & 25.8611 & & \\
\hline & $6-10$ & 22 & 25.1818 & & \\
\hline & $11-15$ & 17 & 24.8235 & & \\
\hline & 16 ve üzeri & 9 & 27.5556 & & \\
\hline
\end{tabular}

Tablo 14 incelendiğinde, yürütülen tez sayıs1 değişkenine göre eğitim inançları ölçeğinde istatistiksel olarak anlamlı farklılık olmadığı görülmektedir ( $>$ >.05). Yürütülen tez sayısı değişkenine göre eğitim inançları ölçeği boyutları puan ortalamaları incelendiğinde, daimici eğitim inancı boyutu puan ortalamalarında, en yüksek puan ortalamasının hiç tez yürütmeyen öğretim elemanlarında $(\bar{x}=27.5455)$, en düşük puan ortalamasının ise 16 ve üzeri tez yürüten öğretim elemanlarında $(\overline{\mathrm{x}}=23.8889)$ olduğu görülmektedir.

Esasici eğitim inanc1 boyutu puan ortalamalarında, en yüksek puan ortalamasının 11-15 arasında tez yürüten öğretim elemanlarında ( $\bar{x}=14.4706)$, en düşük puan ortalamasının ise 16 ve üzeri tez yürüten öğretim elemanlarında $(\bar{x}=12.6667)$ olduğu görülmektedir. İlerlemeci eğitim inancı boyutu puan ortalamalarında, en yüksek puan ortalamasının hiç tez yürütmemiş öğretim elemanlarında ( $\overline{\mathrm{x}}=49.2273$ ), en düşük puan ortalamasının ise 11-15 arasında tez yürüten öğretim elemanlarında $(\overline{\mathrm{x}}=42.2943)$ olduğu görülmektedir. Yeniden kurmac1 eğitim inancı boyutu puan ortalamalarında, en yüksek puan ortalamasının 16 ve üzeri sayıda tez yürüten öğretim elemanlarında ( $\bar{x}=26.8889$ ), en düşük puan ortalamasının ise 11-15 arasında tez yürüten öğretim elemanlarında $(\bar{x}=24.5882)$ olduğu görülmektedir. Varoluşçu eğitim inancı boyutu puan ortalamalarında en yüksek puan ortalamasının 16 ve üzeri sayıda tez yürüten öğretim elemanlarında $(\bar{x}=27.5556)$, en düşük puan ortalamasının ise 11-15 arasında tez yürüten öğretim elemanlarında ( $\bar{x}=24.8235)$ olduğu görülmektedir. 
Tablo 15

İhtiyaç Belirleme Eğilimleri ile Eğitim İnançları Arasındaki İliş̧ki

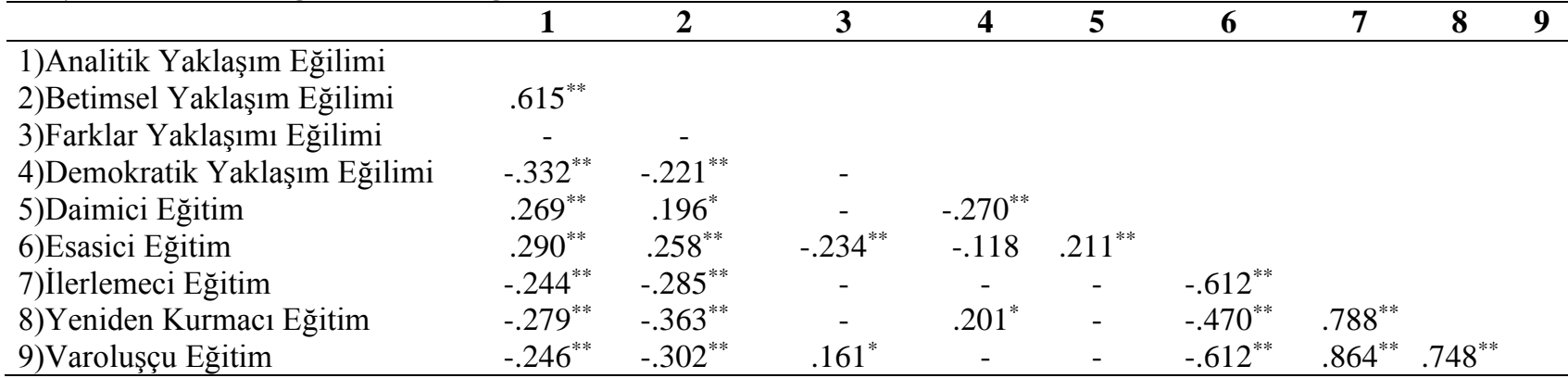

Tablo 15 incelendiğinde, ihtiyaç belirleme eğilimleri ile eğitim inançları arasındaki ilişkide; Analitik yaklaşım eğilimi ile daimici eğitim inançları arasında pozitif yönlü, düşük kuvvette anlamlı bir ilişki $(\mathrm{p}<.05 . \mathrm{r}=.269)$; esasici eğitim inançları arasında pozitif yönlü, düşük kuvvette anlamlı bir ilişki $(\mathrm{p}<.05 . \mathrm{r}=.290)$; ilerlemeci eğitim inançları arasında negatif yönlü düşük kuvvette anlamlı bir ilişki $(p<.05 . r=-.244)$; yeniden kurmacı eğitim inançları arasında negatif yönlü düşük kuvvette anlamlı bir ilişki ( $\mathrm{p}<.05$. $\mathrm{r}=-.279)$; varoluşçu eğitim inançları ile ise arasında negatif yönlü düşük kuvvette anlamlı bir ilişki ( $\mathrm{p}<.05$. $\mathrm{r}=-$.246) olduğu görülmektedir.

Betimsel yaklaşım ile daimici eğitim inançları arasında pozitif yönlü, düşük kuvvette anlamlı bir ilişki $(\mathrm{p}<.05$. $\mathrm{r}=.196)$; esasici eğitim inançları arasında pozitif yönlü, düşük kuvvette anlamlı bir ilişki $(\mathrm{p}<.05 . \mathrm{r}=.258)$; ilerlemeci eğitim inançları arasında negatif yönlü düşük kuvvette anlamlı bir ilişki $(p<.05$. $r=-.285)$; yeniden kurmacı eğitim inançları arasında negatif yönlü orta kuvvette anlamlı bir ilişki $(\mathrm{p}<.05$. $\mathrm{r}=-.363)$; varoluşçu eğitim inançları ile ise arasında negatif yönlü orta kuvvette anlamlı bir ilişki $(\mathrm{p}<.05$. $\mathrm{r}=-.302)$ olduğu görülmektedir.

Farklar yaklaşımı ile varoluşçu eğitim inançları arasında pozitif yönlü düşük kuvvette anlamlı bir ilişki olduğu $(\mathrm{p}<.05 . \mathrm{r}=.161)$; esasici eğitim inançları arasında negatif yönlü, düşük kuvvette ( $p<.05 . r=-.234)$, anlamlı bir ilişki olduğu görülmüştür.

Demokratik yaklaşım ile yeniden kurmacı eğitim inançları arasında pozitif yönlü, düşük kuvvette anlamlı bir ilişki olduğu $(\mathrm{p}<.05 . \mathrm{r}=.201)$, daimici eğitim inançları arasında negatif yönlü, düşük kuvvette, anlamlı bir ilişki $(\mathrm{p}<.05$. $\mathrm{r}=-.270)$; esasici eğitim inançları arasında negatif yönlü, düşük kuvvette, anlamlı bir ilişki ( $\mathrm{p}<.05 . \mathrm{r}=-.118)$ olduğu görülmüştür.

\section{Sonuç, Tartışma ve Öneriler}

Program Geliştirmede İhtiyaç Belirleme Eğilimleri Envanteri boyutları puan ortalamaları incelendiğinde, en yüksek puan ortalamasının betimsel yaklaşım eğiliminde, en düşük puan ortalamasının ise demokratik yaklaşım eğiliminde olduğu görülmüştür. Diğer bir ifade ile çalışma grubunda bulunan öğretim elemanlarının, görece ihtiyaç belirleme yaklaşımlarından betimsel yaklaşımı tercih ettiği ifade edilebilir. Çalışma grubunda bulunan öğretim elemanları demokratik yaklaşımı en az tercih etmişlerdir. Alkın-Şahin, Tunca ve Ulubey (2014) tarafından yapılan araştırmada öğretmen adaylarının betimsel yaklaşımı daha verimli buldukları saptanmıştır. Yazıcı'nın (2017) yaptığ 1 araştırmaya göre müzik öğretmenliği bölümünde eğitim-öğretim görmekte olan öğretmen adaylarının yeğleyişleri de betimsel yaklaşımı desteklemektedir. İlgili alanyazın tarandığında İhtiyaç Belirleme Eğilimleri’nden betimsel yaklaşımın yeğlendiği ve bu yaklaşımın eğitim programlarını şekillendirmesi gerektiği savunulmuştur. Günümüzde Türk Eğitim Sistemi'nin vizyonu ve misyonu, merkeziyetçi bir eğitim anlayışını içermesinden dolayı, betimsel yaklaşımı eğitim-öğretimi işe koşan kişilerin benimsemesinin normal olabileceği düşünülmektedir.

Cinsiyet değişkenine göre ihtiyaç belirleme eğilimleri incelendiğinde, istatistiksel olarak anlamlı bir farklılık olmadığı görülmüsstür. Cinsiyete göre ihtiyaç belirleme eğilimleri boyutları puan ortalamaları incelendiğinde kadınların farklar ve demokratik yaklaşım boyutlarında puan 
ortalamalarının yüksek olduğu, erkeklerin puan ortalamalarının ise analitik ve betimsel yaklaşım boyutlarında yüksek olduğu görülmüştür. Alkın-Şahin, Tunca ve Ulubey (2014) tarafından yürütülen bir araştırmada cinsiyet değişkeninin, ihtiyaç belirleme eğiliminde etkili olduğu saptanmıştır. Aybek ve Aslan (2017) yaptıkları araştırmada cinsiyet faktörünün, ihtiyaç belirleme eğilimlerini etkilediğini ortaya koymuşlardır. Kadınların demokratik yaklaşımı benimsemesinin toplumsal cinsiyet eşitsizliğinden kaynaklandığı düşünülmektedir. Eğitim İnançları Ölçeği puan ortalamaları incelendiğinde, en yüksek puan ortalamasının varoluşçu eğitim inançları boyutunda olduğu, en düşük puan ortalamasının ise esasici eğitim inançları boyutunda olduğu görülmüştür. Diğer bir ifade ile çalışma grubunda bulunan öğretim elemanlarının, görece varoluşçu eğitim yaklaşımını benimsedikleri ifade edilebilir. Çalışma grubunda bulunan öğretim elemanlarının esasici eğitim inancını benimsemedikleri, bunun yerine varoluşçu eğitim anlayışını yeğledikleri saptanmıştır. Yazıcı (2017) tarafından yapılan araştırmada Türkiye'nin farklı coğrafi bölgelerinden seçilen öğretmen adaylarının da varoluşçu eğitim inancını yeğledikleri görülmüştür. İlgili alanyazına bakıldığında öğretmenlerin, öğretmen adaylarının ve akademisyenlerin varoluşçu eğitim inancını benimsedikleri görülmüştür. Öğrenciyi merkeze alan ve daha özgürlükçü bir yapıya sahip olan varoluşçu eğitim inancının benimsenmesi; yaratıcı düşünmeye önem veren, eğitim anlayışı için uygun olduğu düşünülmektedir.

Yaş değişkenine göre ihtiyaç belirleme eğilimleri incelendiğinde istatistiksel olarak anlamlı bir farkl11ık olmadığı görülmüştür. Yaş değişkenine göre ihtiyaç belirleme eğilimleri puan ortalamaları incelendiğinde analitik ve betimsel yaklaşımda en yüksek puan ortalamasının 20-29 yaş aralığındaki öğretim elemanlarında, en düşük puan ortalamasının ise 60 yaş ve üzeri öğretim elemanlarında olduğu; farklar yaklaşımında en yüksek puan ortalamasının 60 yaş ve üzeri öğretim elamanlarında, en düşük puan ortalamasının ise 50-59 yaş aralığındaki öğretim elemanlarında olduğu; demokratik yaklaşımda en yüksek puan ortalamasının 60 yaş ve üzeri öğretim elemanlarında olduğu, en düşük puan ortalamasının ise 30-39 yaş aralığındaki öğretim elemanlarında olduğu görülmüştür. Veriler incelendiğinde yaş faktörünün ihtiyaç belirleme eğilimleri üzerinde herhangi bir etkisinin bulunmadığı görülmektedir. Yaş değişkenine göre eğitim inançlarında istatistiksel olarak anlamlı bir farklılık olmadığı görülmüştür. Yaş değişkenine göre eğitim inançları ölçeği puan ortalamaları incelendiğinde, daimici ve yeniden kurmacı eğitim boyutlarında en yüksek puan ortalamasının 50-59 yaş aralığındaki öğretim elemanlarında, en düşük puan ortalamasının 60 yaş ve üzeri öğretim elemanlarında olduğu; esasici eğitim boyutunda en yüksek puan ortalamasının 20-29 yaş aralığında, en düşük puan ortalamasının 40-49 yaş aralığında olduğu; ilerlemeci eğitim boyutunda en yüksek puan ortalamasının 20-29 yaş aralığında, en düşük puan ortalamasının 60 yaş ve üzeri öğretim elemanlarında; varoluşçu eğitim boyutunda ise en yüksek puan ortalamasının 50-59 yaş aralığında, en düşük puan ortalamasının ise 30-39 yaş aralığında olduğu görülmüştür. Biçer ve Özel (2013) tarafından yürütülen araştırmada, demografik değişkenlerin ihtiyaç belirleme eğilimleri üzerinde herhangi bir etkisinin bulunmadığı ortaya konulmuştur. Saptanan verilere bakıldığında yaş değişkeninin eğitim inançlarına anlamlı bir etkisinin bulunmadığ 1 görülmektedir. Akademik unvan değişkenine göre ihtiyaç belirleme eğilimleri puan ortalamaları incelendiğinde, analitik ve betimsel yaklaşımda en yüksek puan ortalamasının araştırma görevlilerinde, en düşük puan ortalamasının öğretim görevlilerinde olduğu; farklar yaklaşımında en yüksek ortalamasının öğretim görevlilerinde, en düşük ortalamasının araştırma görevlilerinde olduğu; demokratik yaklaşımda ise en yüksek ortalamasının profesör doktorlarda, en düşük ortalamasının ise araştırma görevlilerinde olduğu görülmüştür. Ülkemizde farklı yılarda farklı eğitim programları kullanıldığı için akademisyenler, farklı eğitim programına göre yetişmiştir. Eğitim programlarının değişiklik göstermesi bireylerin üzerinde farklı etki gösterebilmektedir. Araştırma görevlileri yaşça diğer unvana sahip akademisyenlerden küçük olduğu için daha çağdaş bir eğitim programı içerisinde yetiştikleri için analitik ve betimsel gibi geleneksel olmayan, modern bir yaklaşımı benimsedikleri düşünülmektedir. Yaşça büyük olan ve geleneksel eğitim programlarına göre yetişen profesörlerin bu yüzden daha geleneksel yaklaşımları benimsedikleri düşünülmektedir.

Yürütülen araştırma projesi sayısı değişkenine göre ihtiyaç belirleme eğilimleri puan ortalamaları incelendiğinde istatistiksel olarak anlamlı bir farklılık olmadığı görülmektedir. Yürütülen araştırma projesi sayısı değişkenine göre ihtiyaç belirleme eğilimleri puan ortalamaları incelendiğinde, analitik yaklaşımda en yüksek puan ortalamasının 1-5 arasında projeye sahip olan öğretim elemanlarında, en düşük puan ortalamasının 16 ve üzeri projesi olan öğretim elemanlarında olduğu; 
betimsel yaklaşımda en yüksek puan ortalamasının 1-5 arasında projeye sahip olan öğretim elemanlarında, en düşük puan ortalamasının 6-10 arasında projeye sahip olan öğretim elemanlarında olduğu; esasici eğitimde ise en yüksek puan ortalamasının araştırma görevlilerinde, en düşük puan ortalamasının ise öğretim görevlilerinde olduğu görülmektedir. Yürütülen proje sayısı arttıkça çağdaş eğitim yaklaşımlarından uzaklaşıldığı, yürütülen proje sayısı düştükçe de çağdaş eğitim yaklaşımlarına yaklaşıldığ1 saptanmıştır. Sonucun bu şekilde çıkmasının sebeplerinden birinin, yürütülen proje sayısı ile akademisyenlerin yaş ortalamalarının doğru orantılı olması, dolayısıyla yaşça küçük olan akademisyenlerin çağdaş eğitim yaklaşımlarıyla yetişmesinden kaynaklandığ Araştırma görevlilerinin yaşça diğer akademisyenlerden küçük olduğu düşünülürse, esasicilik gibi geleneksel bir eğitim yaklaşımını benimsemelerinin bu çıkarım ile çeliştiği düşünülmektedir.

Yürütülen tez sayısı değişkenine göre ihtiyaç belirleme eğilimleri incelendiğinde analitik ve demokratik yaklaşım boyutlarında istatistiksel olarak anlamlı bir farklılık olduğu görülmektedir. Farklılıkların kaynağına ilişkin yapılan analizlerden anlamlı bir farklılığa ulaşılamamıştır. Yürütülen tez sayısı değişkenine göre ihtiyaç belirleme eğilimleri incelendiğinde betimsel ve farklar yaklaşımında en yüksek puan ortalamalarının 1-5 arasında tez yürüten öğretim elemanlarına, en düşük puan ortalamalarının 11-15 arasında tez yürüten öğretim elemanlarına ait olduğu görülmektedir. Yürütülen tez sayısı bakımından daha tecrübeli akademisyenlerin farklar yaklaşımını ve analitik yaklaşımı benimsemediği, daha çok demoktarik yaklaşımı benimsediği; yürütülen tez sayısı bakımından görece daha tecrübesiz olan akademisyenlerin betimsel, analitik ve farklar yaklaşımını daha çok benimsediği, demokratik yaklaşımı reddettiği araştırmanın bulguları arasındadır.

Cinsiyet değişkenine göre eğitim inançları ölçeği boyutlarında istatistiksel olarak anlamlı bir farklılık olmadığı görülmüştür. Cinsiyete göre eğitim inançları alt boyutları incelendiğinde esasici, yeniden kurmacı, varoluşçu, ilerlemeci eğitim boyutlarında kadınların puan ortalamalarının yüksek olduğu, daimici eğitim inancı boyutunda ise erkeklerin puan ortalamasının yüksek olduğu görülmüştür. Aybek ve Aslan (2017) yaptıkları araştırmada öğretmen adaylarının daimici eğitim anlayışını benimsemediklerini saptamıştır.

Akademik unvan değişkenine göre eğitim inançları incelendiğinde istatistiksel olarak anlamlı bir farklılık olmadığı görülmektedir. Akademik unvan değişkenine göre eğitim inançları puan ortalamaları incelendiğinde, ilerlemeci, yeniden kurmacı ve varoluşçu eğitim inancı boyutu puan ortalamalarında en yüksek puan ortalamalarının öğretim görevlilerinde, en düşük puan ortalamalarının doçent doktorlarda olduğu; esasici eğitimde ise en yüksek puan ortalamasının araştırma görevlilerinde, en düşük puan ortalamasının ise öğretim görevlilerinde olduğu görülmektedir. Esasicilik gibi geleneksel bir eğitim inancını çağdaş eğitim programına göre yetişen genç araştırma görevlilerinin yeğlemesi ve aynı araştırma görevlilerinin bir önceki maddede çağdaş yaklaşımlardan betimsel ve analitik yaklaşımı benimsemesi bir çelişki doğurduğu düşünülmektedir.

Yürütülen araştırma projesi sayısına göre eğitim inançları incelendiğinde esasici ve ilerlemeci eğitimde istatistiksel olarak anlamlı bir farklılık olduğu görülmüştür. Farklılığa ilişkin yapılan analizde, esasici eğitimde farklılığın proje yürütmeyen öğretim elemanları ile 1-5 arasında proje yürüten öğretim elemanları arasındaki farktan; ilerlemeci eğitimdeki farkl11ığın ise 1-5 arasında proje yürüten öğretim elemanları ile 11-15 arasında proje yürüten öğretim elemanlarından kaynaklandığı görülmektedir. Yürütülen araştırma projesi sayısına göre eğitim inançlarında varoluşçu eğitim inancı puan ortalamalarında en yüksek puan ortalamasının 1-5 arasında proje yürüten öğretim elamanlarında, en düşük puan ortalamasının 11-15 arasında proje yürüten öğretim elemanlarında olduğu; daimici eğitim inancı boyutu puan ortalamalarında en yüksek puan ortalamasının hiç proje yürütmeyen öğretim elemanlarında, en düşük puan ortalamasının 16 ve üzeri proje yürüten öğretim elemanlarında olduğu; esasici eğitim inancı boyutunda en yüksek puan ortalamasının 11-15 arasında proje yürüten öğretim elemanlarında, en düşük puan ortalamasının ise 1-5 arasında proje yürüten öğretim elemanlarında olduğu görülmüştür. Altınkurt, Yılmaz ve Oğuz (2012) tarafından yürütülen araştırmada öğretmenlerin daimici ve esasici eğitim anlayışına uzak oldukları, varoluşçu eğitim anlayışına daha yakın olduğu saptanmıştır. Çelik ve Orçan (2016) tarafından yürütülen bir araştırmada Eğitim Felsefesi dersinin öğretmen adayları tarafından benimsenen eğitim felsefeleri üzerinde 
etkisinin olup olmadığ ve demografik değişkenlerin bu inançlar üzerinde etkisinin olup olmadığ1 araştırılmış ve öğretmen adaylarının büyük bir kısmı varoluşçu anlayışı yeğleyip esasici anlayışı reddetmiştir. Sonuçlar, yürütülen araştırma projesi sayısı ile yaş değişkeninin doğru orantılı olduğu düşünüldüğünde, az sayıda araştırma projesi yürüten akademisyenlerin varoluş̧̧u gibi özgürlükçü eğitim anlayışını benimsemelerinin yetiştikleri çağdaş eğitim yaklaşımından kaynaklandığı düşünülmektedir. Çok sayıda araştırma projesi yürüten akademisyenlerin daimici gibi geleneksel bir eğitim anlayışına uzak olmaları ise zaman içerisinde geleneksel yaklaşımı verimsiz bulmaları ya da geleneksel yaklaşımlardan esasiciliği benimsemiş olasılığından kaynaklandığı düşünülmektedir.

Yürütülen tez sayısı değişkenine göre eğitim inançlarında istatistiksel olarak anlamlı bir farkl11ık olmadığ 1 görülmektedir. Puan ortalamaları incelendiğinde, yeniden kurmacı eğitim inanc1 boyutu ve varoluşçu eğitim inancı boyutunda en yüksek puan ortalamalarının 16 ve üzeri tez yürüten öğretim elemanlarına, en düşük ortalamaların 11-15 arası tez yürüten öğretim elemanlarına ait olduğu; daimici eğitim inancı boyutunda en yüksek puan ortalamasının hiç tez yürütmeyen öğretim elemanlarına, en düşük puan ortalamasının 16 ve üzeri tez yürüten öğretim elemanlarına ait olduğu; esasici eğitim inanc1 boyutunda en yüksek puan ortalamasının 11-15 arası tez yürüten öğretim elemanlarına, en düşük puan ortalamasının 16 ve üzeri tez yürüten öğretim elemanlarına ait olduğu; ilerlemeci eğitim inancı boyutunda ise en yüksek puan ortalamasının hiç tez yürütmeyen öğretim elemanlarına, en düşük puan ortalamasının ise 11-15 arası tez yürüten öğretim elemanlarına ait olduğu görülmektedir.

Betimsel yaklaşım ile daimici ve esasici yaklaşım arasında pozitif yönlü, düşük kuvvette bir ilişki olduğu; ilerlemeci, yeniden kurmacı ve varoluşçu eğitim arasında ise negatif yönlü orta kuvvette bir ilişki olduğu görülmüsstür. Sıvacı (2017) tarafından yürütülen bir araştırmada öğretim üyelerinin program geliştirmede ihtiyaç belirleme eğilimlerini belirlemiştir. $\mathrm{Bu}$ araştırmanın sonucuna göre sırasıyla; analitik yaklaşım, betimsel yaklaşım, demokratik yaklaşım ve farklar yaklaşımının güvenilirlik katsayısı sonucuna ulaşılmıştır. Bir önceki maddede ulaşılan sonucun bir benzerine ise bu maddede ulaşılmıştır.

Demokratik yaklaşım ile yeniden kurmacılık arasında pozitif yönlü, düşük kuvvette bir ilişki olduğu, daimici ve esasici eğitim inancı arasında negatif yönlü, düşük kuvvette bir ilişki olduğu görülmüştür. Demoktarik yaklaşımı benimseyen akademisyenler aynı zamanda yeniden kurmacılığı da benimsemiştir. Fakat esasici ve daimici anlayışa bakıldığında aralarında zıt yönlü bir ilişkinin bulunması, her iki eğitim inancının da geleneksel olmasından ötürü çelişki yarattığı düşünülmektedir.

Araştırmanın bulgularına göre öğretim elemanları görece varoluşçu eğitim anlayışını benimsemiş, esasici eğitim anlayışını ise reddetmiştir. Her iki yaklaşımın da çağdaş eğitim anlayışı olması ve akademisyenlerin esasiciliği reddetmesi kafalarda soru işareti bırakmıştır. Sonucun bu şekilde çıkmasının nedenleri yeni bir araştırma konusu doğurmaktadır. Akademisyenlerin çağdaş eğitim inancı yerine geleneksel eğitim inancını benimsemelerinin nedenleri başka bir araştırmanın konusu olabilir. Betimsel yaklaşım ile esasici ve daimi yaklaşım arasında pozitif yönlü bir ilişkinin olması akademisyenlerin arada kalmışlığının bir göstergesi olarak nitelenebilir. Araştırmanın bir diğer sonucu ise daimicilik ve esasiciliğin arasında negatif yönlü bir ilişkinin bulunmasıdır. Bu sonuca göre geleneksel iki anlayış arasında bir kutuplaşmanın olduğu, geleneksel eğitim inancını benimseyen akademisyenlerin de bu kutuplaşmaya katıldıklarının göstergesidir. Yapılacak olan yordama çalışmalarında bu farklılıkların sebebi açıklanabilir.

\section{Yazarların Katkı Oranı}

Bu makaleye birinci yazarın \%50, ikinci yazarın \%50 oranında katkısı vardır.

\section{Çıkar Çatışması}

$\mathrm{Bu}$ çalışmada çıkar çatışması teşkil edebilecek bir durum yoktur. 
Açıklamalar: $\mathrm{Bu}$ çalışma, birinci yazarın ikinci yazar danışmanlığında Kırşehir Ahi Evran Üniversitesi Sosyal Bilimler Enstitüsü’nde tamamladığı yüksek lisans tezinden üretilmiştir.

\section{Kaynaklar}

Adıgüzel, O. C. (2016). Eğitim programlarının geliştirilmesinde ihtiyaç analizi el kitabı. Ankara: Anı Yayıncilik.

Alkın-Şahin, S., Tunca, N. ve Ulubey, Ö. (2014). Öğretmen adaylarının eğitim inançları ile eleştirel düşünme eğilimleri arasındaki ilişki. Illkögretim Online, 13(4), 1473-1492.

Altınkurt, Y., Y1lmaz, K. ve Aytunga, O. (2012). İlköğretim ve ortaöğretim okulu öğretmenlerinin eğitim inançları. Ondokuz Mayıs Üniversitesi Eğitim Fakültesi Dergisi, 31(2), 1-19.

Aybek, B. ve Aslan, S. (2017). Öğretmen adaylarının eleştirel düşünme eğilimleri ile benimsedikleri eğitim felsefelerinin çeşitli değişkenler açısından incelenmesi. Gaziantep University Journal of Social Sciences, 16(2), $373-385$.

Bhattacherjee, A. (2012). Social science research: Principles, methods, and practices. Florida, USA: USF Tampa Library Open Access Collections.

Biçer, H. ve Özel, A. (2013). Öğretmen adaylarının epistemolojik inançları ve benimsedikleri eğitim felsefeleri arasındaki ilişki. Journal of Theory \& Practice in Education (JTPE), 9(3), 229-242.

Brandt, R. S. (2000). Education in a New Era. 2000 ASCD Yearbook. Beauregard St. Alexandria: Association for Supervision and Curriculum Development.

Brown, J. D. (1995). The elements of language curriculum: A systematic approach to program development. Boston: Heinle \& Heinle Press

Çalışkan, N. ve Çangal, Ö. (2013). Yabancılara Türkçe öğretiminde dil ihtiyaç analizi: Bosna-Hersek örneği. Abant İzzet Baysal Üniversitesi Eğitim Fakültesi Dergisi,13(2), 310-324.

Çelik, R. ve Orçan, F. (2016). Öğretmen adaylarının eğitim inançları üzerine bir çalışma. Eğitimde Kuram Ve Uygulama, 12(1), 63-77.

Demirel, Ö. (2007). Eğitimde program geliştirme. Ankara: Pegem A Yayıncılık.

Demirel, Ö. (2015). Ĕ̈itimde program geliştirme: Kuramdan uygulamaya. Ankara: Pegem Akademi.

Dewey, J. and Başman, H. A. (2008). Okul ve toplum. Ankara: Pegem Akademi.

Doğanay, A. ve Mediha, S. (2003). İlköğretim öğretmenlerinin sahip oldukları eğitim felsefelerine ilişkin algılarının değerlendirilmesi "öğretmenlerin eğitim felsefeleri. Türk Ĕgitim Bilimleri Dergisi, 1(3), 1-14.

Duman, B. (2008). Öğrencilerin benimsedikleri eğitim felsefeleriyle kullanıldıkları öğrenme strateji ve öğrenme stillerinin karşılaștırılması. Çukurova Üniversitesi Sosyal Bilimler Enstitüsü Dergisi, 17(1), 203-224.

Ergün, M. (2009). Eğitim felsefesi. Ankara: Pegem Akademi.

Karacaoğlu, Ö. C. (2009). İhtiyaç analizi ve delphi tekniği; ögrretmenlerin eğitim ihtiyacını belirleme örneği. www.eab.org.tr/eab/2009/pdf/264.pdf adresinden 18.03.2017 tarihinde edinilmiştir.

Karslı, M. D. (2007). Eğitim bilimine giriş. Ankara: Pegem Akademi Yayıncılık. 
Kılıç, S. (2013). Sampling methods. Journal of Mood Disorders, 3(1), 44-46.

Küçükahmet, L. (1992). Hizmetiçi eğitim (teori ve uygulamalart). Ankara: G.Ü. İletişim Fakültesi Yayınları.

Küyel, M. T. (1976). Türkiye'de cumhuriyet döneminde felsefe eylemi. Ankara: AÜ Yayınları.

Moss, G. and Lee, C. J. (2010). A critical analysis of philosophies of education and INTASC standards in teacher preparation. The International Journal of Critical Pedagogy, 3(2), 25.

Price, C. P., Jhangiani, R. S., Chiang, I. A., Leighton, D. C. and Cuttler, C. (2017). Research methods in psychology (3rd american edition). Retrieved from https://opentext.wsu.edu/carriecuttler/ in 25.04.2019.

Price, C. P., Jhangiani, R. S. and Chiang, I. A. (2015). Research methods in psychology (2nd canadian editon). Retrieved from www.opentextbc.ca/researchmethods in 25.04.2019.

Saylor, J. G. Alexanderw, M. and Lewis, A.J. (1981). Curriculum plannig for beter learning, holt, rinehart and Winston. New York : Holt. Rinehart \& Winston

Sıvacı, S. Y. (2016, 5-8 Mayıs). Program geliştirmede ihtiyaç belirleme eğilimi envanterinin geliştirilmesi. http://congress.eab.org.tr/2016/media/2016_ozet_kitap.pdf adresinden 18.03.2017 tarihinde erişilmiştir.

Sivac1, S. Y. (2017). Study of need determination tendency of associates on program development. Journal of Current Researches on Educational Studies, 7(1), 87-96.

Sönmez, V. (2002). Eğitimin felsefi temelleri. Ankara: Anı Yayıncılık.

Sönmez, V. (2009) Öğretmen Elkitabı. Ankara: Anı Yayıncılık.

Taymaz, H. (1981). Hizmet içi eğitim. Ankara: Sevinç Matbaası.

Türk Dil Kurumu. $\quad$ (2019). İhtiyaç. http://www.tdk.gov.tr/index.php?option=com_bts\&arama=kelime\&guid=TDK.GTS.58f8d14c d5ae14.43203708 adresinden 10 Mart 2019 tarihinde erişilmiştir.

Westfall, L. (2009). Sampling methods. Retrieved from https://www.westfallteam.com/sites/default/files/papers/Sampling\%20Methods.pdf $\quad$ in 18.03.2017.

Yazıcı, T. (2017). Müzik öğretmeni adaylarının eğitim felsefesi inançları. Kastamonu Eğitim Dergisi, 25(2), 1-16.

Yılmaz, K. Altınkurt, Y. ve Çokluk, Ö. (2011). Eğitim İnançları Ölçeği’nin geliştirilmesi: Geçerlik ve güvenirlik çalışması. Kuram ve Uygulamada Eğitim Bilimleri, 11(1), 335-350.

Yokuş, T. (2014). Müzik öğretmeni adaylarının eğitme öğretme öz-yeterlikleri açısından değerlendirilmesi. SED-Sanat Ĕ̆itimi Dergisi, 2(2), 43-56. 


\section{Extended Abstract}

\section{Introduction}

There are deficiencies or deficits that can be eliminated by appropriate educational activities between the situation in need of education and the desired situation (Demirel, 2015; Küçükahmet; 1992; Taymaz, 1981). The efficiency of the training effectiveness depends on the correct determination of the training need. Because the goals consistent with the need for education can create real and durable teaching goals for the individual. When these definitions in the literature are examined, the philosophy of education can be defined as thinking systematically in order to achieve the desired goals in education. In this research, as educational philosophies; Permanentism, Essentialism, Progressivism, Reconstructivism and Existentialism are discussed. In this context, the aim of the study is to determine the relationship between the instructors' needs-determination tendencies and educational philosophy beliefs and to examine them in terms of various variables.

\section{Method}

The model of the research is a correlative research model due to the examination of the relationship between needs determination tendencies and educational objectives. Correlational research is a kind of non-experimental research where the researcher measures two variables and evaluates the statistical relationship (i.e. correlation) between them, with little or no effort to control external variables. The study group of the research consists of teaching staff selected by appropriate sampling method. It has been implemented online over the internet, taking into account the cost and time issue of data collection in different cities. In the research, the "Needs Determination Tendencies in Program Development Inventory" developed by Sivac1 (2016), the "Educational Beliefs Scale" developed by Yılmaz, Altınkurt and Çokluk (2011) and the "Personal Information Form" developed by the researcher were used as data collection tools.The Needs Determination Tendencies Inventory in Program Development was developed by Sivac1 (2016). The inventory consists of Analytical Approach, Descriptive Approach, Democratic Approach and Differences Approach subscales. There are a total of 12 items in the scale. It is based on ranking. Increasing scores indicate an increase in trend. The highest score that can be obtained from each section is 4, the lowest score is 1 . The first item of each chapter includes the Analytical Approach, the second item is Descriptive Approach, the third item is the Differences Approach, and the fourth item is about the Democratic Approach. When ranking in each section, 1. Preferences are calculated over 4 points, 2. Preferences 3 points, 3. Preferences 2 points, 4. Preferences are calculated over 1 point. Analytical Approach subscale .54; Descriptive Approach subscale .51; The Differences Approach subscale has a reliability coefficient of .44 and the Democratic Approach subscale .49. The scale aims to determine the needs determination tendencies of faculty members in curriculum development (Sivac1, 2017). In this study, it was seen that the analytical approach subscale had a reliability coefficient of .85 , the descriptive approach subscale, .83 , the difference approach subscale .73, and the democratic approach subscale .77 . Educational Beliefs Scale was developed by Y1lmaz, Altınkurt, and Çokluk (2011). It was applied on a sample of 459 people, 154 teachers and 305 prospective teachers. As a result of the exploratory factor analysis; It was determined that it consists of five sub-dimensions including Permanent, Essentialist, Progressive, Reconstructive and Existentialist Educational philosophies and 40 five-point likert type items. The factor load values of the items in the scale in question are between .42 and .74; Item total correlations were between .22 and .90; The reliability coefficients vary between .70 and .91 . In addition, the five-factor structure of the scale was verified by confirmatory factor analysis. In this study, it is seen that the reliability coefficients are .83 in the permanent education dimension, .87 in the essentialist education dimension, .92 in the progressive education dimension, .82 in the reconstructive education dimension and .90 in the existential education dimension. 


\section{Findings}

As a result of the study, when the average of the Needs Assessment Tendencies Inventory is analyzed, it is observed that the highest means tend to descriptive approach and the lowest scores tend to be democratic. When the mean values of Educational Beliefs Scale are examined, it is seen that the highest averages are in the dimension of existentialist education beliefs and the lowest means are in the dimension of progressive education beliefs. There was a positive, low-power relationship between democratic approach and reconstruction. There was a negative, low-power relationship between democratic approach and permanent and essential education. In other words, it can be said that those who adopt analytical and descriptive need determination approach adopt the beliefs of permanent and education, those who adopt the difference approach have existentialist education beliefs, and those who adopt a democratic approach adopt re-education beliefs.

\section{Conclusion, Discussion and Recommendations}

There is a positive, low-strength relationship between the descriptive approach and the perpetual and essentialist approach; On the other hand, it has been observed that there is a negative moderate-strength relationship between progressive, reconstructive and existential education. In a study conducted by Sivaci (2017), it determined the needs determination tendencies of faculty members in program development. According to the results of this research; Reliability coefficient of analytical approach, descriptive approach, democratic approach and differences approach was concluded. A similar result of the previous item is reached in this article.

There is a positive low-power relationship between the differences approach and the existential approach; It has been observed that there is a negative, low-strength relationship between essentialism. Accordingly, it was concluded that the academicians who adopted the existentialist education approach rejected the essentialist education belief. The reason for the adoption of existential education belief in a developing world where ideas are important is that it frees students.

It was observed that there is a positive, low-strength relationship between democratic approach and reconstructionism, and a negative, low-strength relationship between permanent and essentialist education beliefs. Academics, who adopt a democratic approach, have also adopted refiction. It is thought that it is normal for academics who adopt reconstruction to adopt a democratic approach at the same time due to the contemporary and co-usability of both approaches. However, when looking at the essentialist and perennial understanding, it is thought that the existence of an opposite relationship between them creates a contradiction because both educational beliefs are traditional.

According to the findings of the study, the teaching staff adopted the relatively existential understanding of education, and rejected the essentialist understanding of education. The fact that both approaches are contemporary education understanding and academicians' rejection of essentialism left a question mark in the minds. The reasons for the result in this way create a new research topic. It is thought that the determination of a positive relationship between the academicians who adopt the belief of permanent and essential education is due to the fact that both beliefs are traditional education beliefs. Another result of the study is that there is a negative relationship between perennialism and essentialism. According to this result, it is an indication that there is a polarization between the two traditional conceptions and that the academicians who adopt the traditional education belief also participate in this polarization. The reason for these differences can be explained in the predictive studies. 